\title{
To protect and serve
}

\section{Restoring public confidence in the SAPS}

\section{JOHAN BURGER}

jburger@issafrica.org

Persistent incidents of brutality, criminal behaviour and abuse of authority by members of South Africa's police agencies have serious implications for public trust and confidence in the police. A decline in trust and confidence in the police is inevitably harmful to the ability of the government to reduce crime and improve public safety. Firm action is needed to stop the decline in policing standards, which is placing both police officers and civilians at unnecessary risk of injury and death. This article explores the underlying reasons for many of the problems confronting the SAPS and considers how they may be addressed.

South Africa appears to be in a situation where public trust in the police is declining, while fear and mistrust of the police is on the increase. Political commentator, Justice Malala, captured this state of affairs in an article titled 'Our cops can't be trusted: Too many police linked to too many gangsters and killers.' The statement that he is 'afraid of the police' and that '[s] ome of them seem to be at the centre of some of the most heinous crimes and ominous acts ...' gives expression to the impact of increasingly negative reports of police conduct, including acts of corruption, brutality, torture and indifference.

Both perceptions and incidents of police brutality and abuse of authority are likely to have a negative impact on the legitimacy of the police. The implications for the police of such negative perceptions were highlighted by the Mollen Commission, set up to investigate corruption in the New York Police Department (NYPD), in their report in 1994: ${ }^{2}$

\footnotetext{
* Johan Burger is a senior researcher in the Crime and Justice Programme at the ISS.
}

\begin{abstract}
Regardless of the truth of this perception, it is the perception that often matters. And this perception poisons relations between the community and the police, compromising the credibility of the vast majority of honest and dedicated cops who need the community's cooperation to carry out their difficult jobs effectively.
\end{abstract}

Reports of police brutality and criminal activity tend to result in police leadership trying to downplay the problem or distract the public in an effort to manage the image of the police organisation. No matter how persistent reports of police malfeasance are, police leadership typically try and portray these as isolated incidents. Nevertheless, problems continue as the organisational factors that contribute to the problem remain unchanged.

\section{EXTENT OF THE PROBLEM}

Allegations of misconduct and illegal activity have been levelled against all strata of the South African Police Service (SAPS), from the National 
Commissioner, General Bheki Cele, to the lowest ranking officials. In 2011 the Sunday Times newspaper published allegations that Cele had irregularly approved a R500 million lease for new police premises in Pretoria from a businessman, Roux Shabangu, who was said to have close ties to ANC leaders. An investigation into these allegations by the Public Protector resulted in a finding that inter alia, the conduct of the National Commissioner was 'improper, unlawful and amounted to maladministration. ${ }^{3}$ For several weeks this matter received prominent media coverage and at the time of writing the recommendations of the Public Protector had not been acted on by the Cabinet.

Shortly after these allegations came to light the South African Police Union (SAPU) publicly accused the Commissioner of nepotism, arguing that he had appointed close family members and friends to senior positions in the police ahead of other better-qualified members and without following normal procedures. ${ }^{4}$ Public debate about the suitability of the Commissioner's leadership of the SAPS followed and most opposition political parties called for his dismissal. ${ }^{5}$

The SAPS Crime Intelligence Division has also been the subject of allegations and reports of misconduct and abuse of power. During the Scorpions' (Directorate for Special Operations) investigation into the corrupt activities of former police commissioner, Jackie Selebi, and his subsequent trial three years later, this unit engaged in unlawful activities, such as interfering with key state witness Glen Agliotti. ${ }^{6}$ This led to criminal charges being laid against the previous Head, of the Division Mulangi Mphego. Mphego later resigned and his case was struck off the court roll due to prosecutorial negligence.?

More recently, in April 2011 allegations were made against the current head of Crime Intelligence, Major General Richard Mdluli and other senior officers. During investigations into the activities of Czech fugitive and alleged organised crime boss, Radovan Krejcir by the SAPS Directorate for Priority Crime
Investigations (also known as the Hawks), it was claimed that SAPS Crime Intelligence officers allegedly illegally tapped the telephones of the investigators and shared the information with Krejcir, thereby jeopardising the case. ${ }^{8}$ Shortly thereafter, the Hawks charged Mdluli, along with two other senior crime intelligence officers and a court orderly, with a murder that took place a decade ago. ${ }^{9}$ During his bail application, Mduli presented to the court a report containing details of an alleged conspiracy by high-level ANC members to undermine President Jacob Zuma's attempt to secure a second term of office. ${ }^{10}$ Thus, for a sustained period of time the media carried allegations of police at the highest levels of the organisation being involved in corrupt and criminal activities and of using police intelligence resources for political purposes.

With such allegations levelled at those at the top of the SAPS it is not too surprising that there were substantial problems occurring lower down the ranks. During the first half of 2011 there were a number of high profile incidents where SAPS members used excessive force under circumstances where it was not justified. In two separate cases CCTV cameras filmed abusive conduct by members of the SAPS Tactical Response Unit: one at a restaurant in Melville and another at a bar in Hillbrow, Johannesburg. ${ }^{11}$

In April and May 2011 there were also numerous media reports of incidents of police brutality and abuse of authority. Among the more prominent incidents was the assault and killing of Andries Tatane by members of the Public Order Police Unit (POP) during a protest march in Ficksburg, Free State, on April 13, $2011 .{ }^{12}$ A video of this incident was broadcast on the public broadcaster's prime time television news.

In yet another incident (on April 23, 2011) the Cape Argus newspaper carried footage of the police assaulting the owner and patrons of a sports bar in Cape Town. ${ }^{13}$

The public outcry that followed Tatane's death, even from within the ANC, elicited from Cele an 
announcement that all members (approximately 8 500) of the POP units would undergo a refresher course. ${ }^{14}$ That gesture would however have been unlikely to have any effect on the negative public perception of the police created by the Tatane killing.

This perception was strengthened by the fact that a few days later, on April 26, a woman (Jeanette Odendaal) was shot and killed in her car by a police sergeant outside the Kempton Park police station in Johannesburg. ${ }^{15}$ She allegedly crashed into a stationary police vehicle when she parked outside the police station. She was shot in the head by a police officer whilst sitting in her vehicle. On the same day two other cases of police brutality were brought before the courts in KwaZulu-Natal. ${ }^{16}$ In the one incident, in Greytown, five policemen allegedly strangled a person in custody while in the other, in Hammersdale, fifteen policemen allegedly beat a suspect to death..$^{17}$

These were not isolated incidents, as claimed by SAPS leadership, ${ }^{18}$ but rather examples of a widespread and growing organisational problem within the SAPS. ${ }^{19}$ This trend was noted at presidential level with Jacob Zuma expressing concern about police brutality and saying ' $[\mathrm{w}] \mathrm{e}$ cannot have this culture from [the] police. ${ }^{20}$ And on 16 March 2011, the chairperson of the National Assembly Portfolio Committee on Police, Sindi Chikunga, stated that MPs in the committee were getting more reports of torture by police '... not seen since apartheid. ${ }^{21}$

Confirming that the incidents of police abuse were not simply isolated incidents, the Independent Complaints Directorate (ICD) Annual Report for 2009/10 revealed that in the last twelve years the total number of complaints against the police increased by $146 \%$ while the number of criminal cases opened against police officials increased by $285 \%{ }^{22}$

Given the extent to which police deviance is seen as widespread and persistent, it is important to consider the long-term effect it may have on the relationship or social contract between citizens and the state in relation to law enforcement.

\section{IMPLICATIONS FOR THE POLICE AND FOR POLICING}

The importance of sound police community relations for effective crime fighting was emphasised in a recent British Home Office publication in support of community or 'neighbourhood policing. ${ }^{23}$ In its publication the Home Office remarked, for example, that:

neighbourhood policing is about fighting crime more intelligently and building a new relationship between the police and the public - one based on active cooperation rather than simple consent.

The South African equivalent to neighbourhood policing is called 'sector policing'. According to the police this is a practical form of community policing and essentially means policing in small and more manageable sectors of a police precinct area. ${ }^{24}$ Community policing philosophy and its operational expression, sector policing, is heavily dependent on good relations and cooperation between the police and communities and, therefore police legitimacy. ${ }^{25}$ However, in spite of community policing being expressed in law through the South African Police Service Act, 1995 (Act No. 68 of 1995), after the first few years after democratisation in 1994, the SAPS gradually forewent the concept in favour of more traditional law enforcement and punitive methods of crime fighting. ${ }^{26}$ This was largely as a result of political and public pressures on the police to 'do something' about the high levels of violent crime, and the fact that the motivation for community policing was more concerned with achieving political than policing objectives. ${ }^{27}$

According to Professor John Casey (City University of New York), in his study on international and transnational policing practices, the possibilities for community policing depend to a large extent on a number of conditions. ${ }^{28}$ Amongst his list of nine conditions the following four are particularly relevant for the South African situation:

- Stability and community cohesion. The essence here is political stability and shared values. 
- Pay, motivation and morale of police. This condition refers to low morale as a result of 'serious management issues' and corruption, while low pay tends to attract poorly educated persons with 'a general lack of respect for policing as an occupation'.

- Trust in the police. Trust is both a desired outcome of community policing and a precondition for its success.

- Political will and commitment to change: This condition includes a commitment by government and police management to implement community policing and 'to firm action on key contextual issues such as corruption, human rights abuses, and excessive use of force. ${ }^{29}$

It is arguable that South Africa currently does not properly meet any of these four conditions. This largely explains the SAPS' lukewarm attitude towards community policing and to a large extent also sector policing.

That the SAPS is not adequately implementing sector policing nine years after its formal introduction in $2002^{30}$ suggests that they no longer regard it as a priority. Further evidence for this can be found in the Strategic Plan of the South African Police Service 2010-2014 that underlines the secondary position of community policing in favour of the intensification of the fight against crime and corruption'. Concepts such as 'community policing,' 'partnership policing' and 'sector policing' receive scant mention in the Strategic Plan. ${ }^{31}$

Since public trust and confidence in the police are prerequisites for effective policing in a democracy, ${ }^{32}$ alienation between police and the public has a number of negative consequences. The police are increasingly pushed behind the 'thin blue line' where an 'us versus them' attitude is nurtured, and the public is generally seen by the police as the 'enemy'. As a result the police stand to lose the public as partner in the fight against crime and as an invaluable source of information. In a recent article on public trust and police legitimacy, Bradford and Jackson argue that '...if people do not trust that the police have their interests at heart and believe there is a wide gap between the values of the two parties - very possibly because they themselves or people they know have been treated unfairly by officers in the past - they may withdraw from engagement and fail to offer assistance. ${ }^{33}$

Andrew Faull, a researcher with the Crime and Justice Programme at the Institute for Security Studies, in a 2010 study involving fifteen focus groups to explore public experiences and perceptions of police and police corruption in South Africa, found that 'despite constant reductions in overall crime over the past decade, public perceptions of police remain fairly negative. ${ }^{34}$ The participants in these focus groups did not wish for police who were effective in 'fighting crime' but for police that were 'polite and respectful. ${ }^{35}$

In the United States, in the aftermath of the racial tensions and social unrest of the 1960s the police also reacted with a 'get tough' policy. ${ }^{36}$ This resulted in widespread violence between the police and largely black communities, leading to a renewed interest in improving police effectiveness. ${ }^{37}$ In a 1968 report on the ghetto riots in the United States the National Advisory Commission on Civil Disorders (the Kerner Commission) outlined the problem as follows:
The policeman in the ghetto is a symbol of increasing bitter social debate over law enforcement. One side, disturbed and perplexed by sharp rises in crime and urban violence, exerts extreme pressure on police for tougher law enforcement. Another group, inflamed against the police as agents of repression, tends toward defiance of what it regards as order maintained at the expense of justice. ${ }^{38}$

The SAPS currently find themselves in much the same position when they police 'service delivery' protests, which are an expression of citizen objection to the failure of the state to meet their expectations. The result is often a confrontation between the police and large crowds of angry people, with the police representing the state and its failures. This only contributes to further 
alienation between the police and communities, which is exacerbated when the police show little or no restraint.

\section{FINANCIAL IMPLICATIONS}

Unlawful and ill-disciplined actions also come at a high financial cost to the state. On 29 March this year the Minister of Police admitted in parliament that civil claims against the police had increased by $33 \%$ in the last financial year from $\mathrm{R} 87,2 \mathrm{~m}$ in $2008 / 09$ to $\mathrm{R} 115,9 \mathrm{~m}$ in $2009 / 10 .^{39}$ These figures might have been lower had it not been for the fact that the police's Legal Services Unit appears to have a policy of challenging every civil claim irrespective of the merits of individual cases and in spite of advice to consider out of court settlements in cases with a limited prospect of success. ${ }^{40}$

This is an irresponsible approach that not only flies directly against the letter and spirit of the Public Finance Management Act, 1999 (Act No.1 of 1999), but also shows disregard for the additional and unnecessary legal costs of civil cases where the judgment goes against the police. This approach to departmental expenditure of public funds may very well fall within the ambit of the Act. In Section 1 of the Act 'fruitless and wasteful expenditure' is defined as an 'expenditure which was made in vain and would have been avoided had reasonable care been exercised'. Similarly, section 2 explains the object of the Act as 'to secure transparency, accountability, and sound management of the revenue, expenditure, assets and liabilities of the institutions to which this Act applies.'

In an effort to address rising concerns about the increase in civil claims and the concomitant financial burden on the police budget the Minister of Police, Nathi Mthethwa, in a written reply to a question in Parliament on March 29, 2011, announced the creation of a new Litigation and Administration Unit as part of a 'turnaround strategy.41 Of particular interest is his reference to the development of a case management strategy as an integral part of the turnaround strategy that, inter alia, is aimed at:
- A coherent policy on settlement of matters, whose essential feature would be a process of ensuring that cases that indicate settlement need not unnecessarily become litigious before such is considered.

- Recovering the costs from police officials who have acted beyond their authority. ${ }^{42}$

These are early days and it remains to be seen whether the new strategies will bring about any improvement. At least these strategies show some recognition of the importance of managing civil claims in a responsible manner and, even more importantly, that there should be personal financial implications as part of the overall consequences for members who abuse their authority. It is all too apparent that in the past members generally considered it the state's responsibility to pay for their misconduct and therefore disregarded civil claims as a deterrent. In this regard, in a relevant study on police litigation in Australia, it was concluded that:

... civil litigation can form part of a regulatory web for controlling police misconduct and misbehaviour, and should be seen as a positive tool for police management to identify problem situations and behaviours and develop improved training and prevention systems. ${ }^{43}$

For Mthethwa the obvious lesson from the Australian study is that he should not limit the engagement with civil claims to that outlined above, but should use these, and complaints against the police, to identify systemic problems within the police so that appropriate policy and other interventions may be developed and implemented.

\section{WHAT CAN BE DONE TO 'FIX' THE SAPS?}

The previous national commissioner of the SAPS, Jackie Selebi, was forced to leave the Service at the end of June 2009, when his extended contract expired. He left behind an organisation that was deeply scarred by the allegations that he had close ties to individuals involved in organised crime. In 2010 Selebi was convicted on a charge of 
corruption and sentenced to fifteen years in prison. ${ }^{44}$ The outcome of this case was preceded by a complex and prolonged investigation and prosecution that revealed a deeply troubled police service led by a man the judge castigated for having a complete lack of integrity. This affected both civilian trust in the police and internal morale. Unfortunately Selebi's conviction did not result in any perceptible improvements to the way in which the organisation deals with corruption and criminality within the police.

Similar allegations of corruption, maladministration, nepotism, intimidation and criminality were made about the staff of the Department of Correctional Services after the murder of a senior Correctional Services member in KwaZulu-Natal in 2000. In that instance the President appointed a judicial commission of inquiry, headed by Judge Thabani Jali, to thoroughly investigate these allegations and to make comprehensive recommendations for improvement. ${ }^{45}$ While the Jali Commission was criticised for taking too long (its final report was submitted in December 2005), it helped to expose the extent of the corruption problem within the department and made recommendations as to how these could be addressed. ${ }^{46}$

Had these recommendations been implemented properly, it is possible that the incidence of corruption in the department would have been addressed, and the treatment of prisoners by warders improved. The Commission did have the effect of stimulating the Portfolio Committee on Correctional Services to take their oversight role more seriously and to hold regular reporting meetings with the department to monitor progress in respect of the recommendations of the Commission and the reports by the Auditor General. While many of the recommendations by the Jali Commission have not yet been acted upon, the Commission did serve an important function of bringing to light the extent of the problem within prisons and providing the basis for advocacy to address these problems.

This raises the question of whether a judicial commission of inquiry into police conduct might not go some way towards providing a basis on which to address the problems in the police.

An example of an effective independent inquiry is the Mollen Commission of Inquiry into police corruption in the New York City Police Department (NYPD) that took place in 1992. The findings of the Mollen Commission, of the nature and extent of corruption within the NYPD, as well as the recommendations for preventing and detecting are instructive. ${ }^{47}$ In spite of the NYPD leadership denying that corruption was a serious problem, the Commission found that:

$$
\begin{aligned}
& \text { Today's corruption is far more criminal, violent } \\
& \text { and premeditated than traditional notions of } \\
& \text { police corruption suggest and far more } \\
& \text { invidious ... Testimony and field investigations } \\
& \text { demonstrated that its most salient forms include } \\
& \text { groups of officers protecting and assisting drug } \\
& \text { traffickers for often sizable profits - stealing } \\
& \text { drugs, guns and money - and often selling the } \\
& \text { stolen drugs and guns to or through criminal } \\
& \text { associates; committing burglary and robbery; } \\
& \text { conducting unlawful searches of apartments, } \\
& \text { cars and people; committing perjury and } \\
& \text { falsifying statements; and sometimes using } \\
& \text { excessive force ... }
\end{aligned}
$$

It is increasingly clear that poor management supervision, training and even recruitment are at the root of many of the problems within the SAPS. For example, an internal investigation by the SAPS's Policy Advisory Council, detailed in two reports for the period November 2006 to October 2008, uncovered a range of basic deficiencies that refer, inter alia, to poor discipline, weak command and control, high levels of corruption, etc. ${ }^{49}$ The Policy Advisory Council was established by the National Commissioner of the SAPS in 2006 'to advise him on the levels of service delivery and crime in the country. ${ }^{50}$ The Advisory Council comprised of 14 retired SAPS commissioners (current ranks would be at the level of lieutenant general) chaired by a former Deputy National Commissioner. ${ }^{51}$

Sub-committees of the Advisory Council visited police stations throughout the country and 
provided regular interim reports to the National Commissioner. However, although the latter announced the appointment of management task teams to attend to issues raised by the Council, , $^{52}$ no evidence could be found that SAPS top management acted on any of the findings and recommendations of the Advisory Council. Amongst an array of findings the Council, for example, remarked as follows on command and control in the SAPS:

There is a general lack of command and control within the Police Service at local level.

Resultant poor levels of discipline and high levels of corruption is of serious concern. ${ }^{53}$

In their second report, a year later in 2008, the Council again expressed the 'firm opinion' that:

...many of the problems of the Police are the direct result of a "breakdown" in command and control and a lack of supervision in certain areas. In most instances poor service delivery, mal-administration, ill-discipline and corruption have at its core the lack of supervision and control. ${ }^{54}$

The Council also criticised the absence of regular inspections at police stations and the inability of the SAPS' National and Provincial Inspectorates to carry out their mandates..$^{55}$ An efficient inspectorate should be able to identify and address most of the deficiencies that exist at police stations and units. In fact, they should be doing what the Policy Advisory Council was eventually appointed to do.

So, could a judicial commission of inquiry provide the basis for an overhaul of the SAPS and address the crises in public accountability it faces? Given the fact that (i) the nature of the problems facing the SAPS and underlying poor policing have been identified already and have been known to both Cabinet and police managers; and (ii) the recommendations of high-level panels have failed to be implemented, it is debatable whether a judicial commission of inquiry would be able to succeed where others have proved to be ineffective. In addition, inaction on behalf of the
Cabinet in the face of findings by the Public Protector that the Commissioner of Police was indeed responsible for mismanagement and unlawful conduct in relation to the procurement of property by the SAPS suggests that there may be insufficient political will to undertake such an intervention; let alone push for the implementation of what are likely to be hard hitting recommendations.

There are however a number of advantages to having a judicial inquiry, the most important being that it would go some way towards responding to the public desire to see the serious problems of police mismanagement being properly addressed. In order to have the desired effect the inquiry would have to be independent; would have to do its work openly and transparently (unlike the secrecy that surrounded the Khampepe Commission); thirdly, it should allow for presentations from individuals and groups outside the police; and should involve experts other than serving police officers as members of the commission. In other words, it should function more like the Goldstone Commission of the early 1990s than the Jali Commission.

The Goldstone Commission, chaired by Judge Richard Goldstone, was set up in 1991 as a structure of the National Peace Accord agreed to between the parties working towards a negotiated political settlement in South Africa. ${ }^{56}$ The objectives of the Commission were 'to inquire into the phenomenon of public violence and intimidation in the Republic, the nature and causes thereof, and what persons were involved therein; inquire into any steps that should be taken in order to prevent public violence and intimidation; and to make recommendations to the State President in respect of public violence or intimidation. ${ }^{57}$ The Commission was eventually authorised (in 1992) to appoint its own independent investigation teams that made them less reliant on the police and enabled them to gather information on allegations, including allegations against the police, more efficiently and quickly. However, political interference that saw the release of the final report of the Goldstone 
Commission being delayed because of the extent of malfeasance in the old South African Police force, should be avoided.

The terms of reference for a commission of inquiry would need to include at least the following terms: To conduct an investigation (a) to determine the nature and extent of police criminality, including acts of brutality, torture and corruption; (b) to establish the root causes of the problem; and (c) to make recommendations on measures to correct the problem areas.

\section{CONCLUSION}

If democratic policing is what we want in South Africa it must be obvious that the current and ongoing state of affairs as far as our police and policing practices are concerned, cannot be tolerated. It may be acceptable in an authoritarian state, but not in a democracy. If what increasingly begins to look like a slide towards authoritarian police practices is allowed to continue we face a dangerous future. Firm action is needed to stop what is happening with the police and an urgent intervention is required. It is in the interest not only of all South Africans, but also of the professional and dedicated police members who are inevitably caught up and tarnished by what is happening around them.

A commission of inquiry is not the only route to take in improving policing. In the absence of an obvious alternative however, it does appear to be sensible to establish an independent structure with the capacity to thoroughly assess the functioning of the SAPS and its leadership. This should have occurred the moment Selebi was found guilty of corruption, so that there could have been a fresh start. However, there has been little difference in the response of SAPS leadership to ongoing problems of police brutality and corruption. SAPS leadership have either remained silent, denied that there is a problem, attempted to distract the public from the initial problem (i.e. police brutality) by pointing at other problems (i.e. the killings of police officials), or attacked those who have raised the problems.
What is needed is a comprehensive strategic plan that clearly explains how the SAPS will become a professional policing agency in the foreseeable future. Such a plan must be able to logically demonstrate how new policies, systems and procedures will ensure that all police members will become widely respected by the public because they are well trained, adhere to a higher standard of conduct than the average citizen and operate in a respectful and accountable manner. It has been done in other countries and can be done in South Africa. It is now time for all South Africans to demand a professional and depoliticised police service that upholds the Constitution and acts in the interest of all people.

To comment on this article visit http://www.issafrica.org/sacq.php

\section{NOTES}

1. Justice Malala, 'Our cops can’t be trusted: Too many police linked to too many gangsters and killers', Times Live, March 27, 2011, http://www.timeslive.co.za/ opinion/columnists/article990597.ece/Our-cops-cantbe-trusted (accessed April 28, 2011).

2. The City of New York, Report by the Commission to Investigate Allegations of Police Corruption and the Anti-Corruption Procedures of the Police Department, Chaired by former judge Milton Mollen, July 1994, http://en.wikipedia.org/wiki/Mollen_Commission (accessed April 28, 2011), 4-5.

3. Public Protector: South Africa (Advocate Thuli Madonsela), Report on an investigation into complaints and allegations of maladministration, improper and unlawful conduct by the Department of Public Works and the South African Police Service relating to the leasing of office accommodation in Pretoria, Report No. 33 of 2010/2011, February 23, 2011, http://www. pprotect.org/library/investigation_report/investigation _report.asp (accessed March 27, 2011), 89.

4. Stephan Hofstatter \& Mzilikazi wa Afrika, 'All in the family: Maj-Gen Ngcobo now earns R805 188 a year', Times Live, March 5, 2011, http://www.timeslive.co.za/ Politics/article950794.ece/All-in-the-family (accessed March 15, 2011).

5. See for example calls by political parties and others in Times Live, Cele's 'shady' head office deal put on ice, Aug 17, 2010, http://www.timeslive.co.za/local/ article608371.ece/Celes-shady-head-office-deal-puton-ice? service $=$ print $($ accessed May 23, 2011); Mike Smith's Political Commentary, May 7, 2011, http://mspoliticalcommentary.blogspot.com/2011/05/ police-commissioner-says-we-do-not.html (accessed May 23, 2011; Dennis Worral, Insight, A tragedy which was waiting to happen, April 19, 2011, omegainvest.co.za/newsletters/insightafrica/19April.../19-April-2011.pdf (accessed May 23, 2011). 
6. The State and Jacob Sello Selebi, Case No: 25/09, South Gauteng High Court, Judgment by Judge Joffe, July 5, 2010, http://www.saflii.org/za/cases/ZAGPJHC/ 2010/53.html (accessed February 12, 2011). See in particular pp.5-13. Also see Selebi's journey with the law, IOL, July 10, 2010, http://www.iol.co.za/news/ south-africa/selebi-s-journey-with-the-law1.488560 ? ot=inmsa.ArticlePrintPageLayout.ot (accessed May 23, 2011).

7. Jackie Mapiloko, 'Court strikes Mphego matter from the roll', Mail \& Guardian Online, May 10, 2010, http://mg.co.za/article/2010-05-10-court-strikesmphego-matter-from-the-roll (accessed April 30, 2011).

8. Werner Swart, Sashni Pather, Stephan Hofstatter, Mzilikazi wa Afrika, \& Shanaaz Eggington, 'Beeka exposed as SA spy', Times Live, March 26, 2011, http://www.timeslive.co.za/local/article988986.ece/Bee ka-exposed-as-SA-spy (accessed April 29, 2011).

9. 'Mdluli in court on murder charge', News24, March 31, 2011, http://www.news24.com/SouthAfrica/News/ Mdluli-in-court-on-murder-charge-20110331 (accessed April 29, 2011); '4th man held in Mdluli murder case', News24, April 1, 2011, http://www. news24.com/SouthAfrica/News/4th-man-held-inMdluli-murder-allegations-20110401 (accessed April 29, 2011).

10. SAPA, Mdluli claims high-level conspiracy, April 8, 2011, http://news.za.msn.com/article.aspx?cpdocumentid=156924691 (accessed May 23, 2011).

11. 'ICD wades through cop brutality cases', News 24 , March 17, 2011, http://www.news24.com/SouthAfrica/ News/ICD-wades-through-cop-brutality-cases20110317 (accessed April 30, 2011).

12. 'Police brutality 'isolated' - Cele', IOL News, April 28, 2011, http://www.iol.co.za/news/crime-courts/policebrutality-isolated-cele-1.1061767 (accessed April 30, 2011).

13. Cops "beat club owner on camera", IOL News, April 28, 2011, http://www.iol.co.za/news/crimecourts/cops-beat-club-owner-on-camera-1.1062158 (accessed May 2, 2011).

14. Ibid.

15. Ibid. 'Police brutality 'isolated' - Cele'. Also see 'Mystery as killer cop snaps', IOL News, April 28, 2011, http://www.iol.co.za/news/crime-courts/mystery-askiller-cop-snaps-1.1061668 (accessed May 2, 2011).

16. Ibid, 'Police brutality 'isolated' - Cele'

17. Ibid.

18. Ibid.

19. See for example Graeme Hosken, $I O L$, 'Why SA cops are so brutal', May 26, 2011, reporting on an ISS seminar titled 'South African policing and the use of force: Challenges and Solutions', May 25, 2011, Pretoria, http://www.iol.co.za/news/crimecourts/why-sa-cops-are-so-brutal-1.1074181 (accessed May 26, 2011).

20. 'Police brutality "a concern"', IOL News, April 28, 2011, http://www.iol.co.za/news/crime-courts/policebrutality-a-concern-1.1062305 (accessed May 14, 2011).

21. Wyndham Hartley, 'More reports of police torture', Business Day, March 16, 2011, http://www.businessday.
co.za/articles/Content.aspx?id=137297 (accessed April $30,2010)$.

22. Independent Complaints Directorate (ICD), Annual Report 2009/10, http://www.icd.gov.za/documents/ annual_reports.asp (accessed February 16, 2011), $69 ; 101$.

23. Cited by John Casey, Policing the World: The Practice of International and Transnational Policing, Durham (North Carolina): Carolina Academic Press, 2010, 65.

24. South African Police Service, Sector Policing, http://www.saps.gov.za/comm_pol/sector_policing/sect or_policing.htm (accessed May 16, 2011).

25. See for example the discussion in Lawrence W. Sherman, Policing for crime prevention, in LW Sherman, D Gottfredson, D Mackenzie, J Eck, P Reuter \& S Bushway, Preventing crime: what works, what doesn't and what's promising, US National Institute of Justice, 1998, http://www.ncjrs.gov/works/chapter8. htm (accessed May 16, 2011), Chapter 8, par.7.

26. See the discussion on community policing in South Africa in Johan Burger, Strategic perspectives on crime and policing in South Africa, Pretoria: Van Schaik Publishers, 2007, 97-104.

27. Ibid, 99-103.

28. John Casey, Policing the World, 75.

29. Ibid.

30. 'Sector policing delay unacceptable', News24, May 30, 2011, http://www.news24.com/SouthAfrica/Politics/ Sector-policing-delay-unacceptable-20110330 (accessed May 16, 2011).

31. Strategic Plan of the South African Police Service 2010 - 2014, pp 8, 12. Available at http://www.google.co.za/ search?q=strategic + plan + of + the + South + African + Police + Service $+2010+-+2014 \&$ ie $=$ utf $-8 \&$ oe $=$ utf $-8 \&$ aq $=$ t\&rls=org.mozilla:en-US:official\&client=firefox-a (acccessed 4 July 2011).

32. See, for example, the Geneva Centre for the Control of Armed Forces, International Police Standards: Guidebook on Democratic Policing, 2009, http://www.google. co.za/search? source=ig\&hl=en $\& \mathrm{rlz}=\& \mathrm{q}=$ international+ police+standards\&aq $=0 \& a q i=g 2 \& a q l=\& o q=$ International+Police+Standards $>$ (accessed April 22, 2011), 12.

33. Ben Bradford \& Jonathan Jackson, 'Public trust and police legitimacy in Great Britain: Short term effects and long-term processes', in Jonathan Jackson, Why Britons trust their police, Academia.Edu, March 2, 2011, http://1se.academia.edu/ JonathanJackson/Papers/419215/Why_Britons_trust_ their_police (accessed May 26, 2011), 6.

34. Andrew Faull, 'When I see them I feel like beating them': Corruption and the South African Police Service, SA Crime Quarterly 34, December 2010, 33-40 (39-40).

35. Ibid

36. Charles R Swanson, Leonard Territo \& Robert W Taylor, Police Administration: Structures, Processes and Behavior (Fifth Edition), New Jersey: Prentice Hall, 2001, 7.

37. Ibid.

38. U.S. National Advisory Commission on Civil Disorders, Reports of the national Advisory Commission on Civil Disorders (Washington, D.C.: 
Government Printing Office, 1968, p.157, cited by Charles R Swanson, Leonard Territo \& Robert W Taylor, Police Administration, 7.

39. Wyndham Hartley, 'Police minister to stem legal claims', Business Day, March 30, 2011,

http://www.businessday.co.za/articles/Content.aspx?id $=138574$ (accessed May 2, 2011).

40. Personal interview, Major General Christie van der Westhuizen (Ret), formerly attached to Legal Services at SAPS Head Office, April 13, 2011.

41. Wyndham Hartley, 'Police minister to stem legal claims.

42. Ibid.

43. Janet Ransley, Jessica Anderson \& Tim Prenzler 'Civil Litigation Against Police in Australia: Exploring Its Extent, Nature and Implications for Accountability', The Australian and New Zealand Journal of Criminology, Volume 40, Issue 2, August 2007 (143160), http://www.atyponlink.com/AAP/doi/abs/10.1375/ acri.40.2.143 (accessed April, 24, 2011), 158.

44. The trial court, during November 2010, granted Selebi leave to appeal against his conviction.

45. See for example the useful summary of the Report of the Jali Commission of Inquiry (the original report is 1800 pages) by Anthea van den Berg, Summary and comment on the Final Report of the Judicial Commission of Inquiry into allegations of corruption, maladministration and violence in the Department of Correctional Services - the 'Jali Commission', Civil Society Prison Reform Initiative (CSPRI), Research report No 13, October 27, 2009,

http://www.communitylawcentre.org.za/search_rss?Sea rchableText $=J a l i+$ Commission + of + Inquiry \&Title $=\& D e$ scription=\&submit=Search (accessed May 3, 2011).

46. Ibid, 48 .

47. The City of New York, Report by the Commission to Investigate Allegations of Police Corruption.

48. Ibid, 10 .

49. SAPS Policy Advisory Council, Reports for November 2006 to October 2007 and November 2007 to October 2008, Unpublished, 2007 \& 2008 respectively, Pretoria

50. SAPS Policy Advisory Council, Report for November 2006 to October 2007, 1.

51. Ibid, 2.

52. Ibid, 4.

53. Ibid, 40 .

54. SAPS Policy Advisory Council, Report for November 2007 to October 2008, 48.

55. Ibid. Also see Bilkis Omar, 'Inspecting the SAPS National Inspectorate', ISS Paper 207, Institute for Security Studies, December 2009.

56. Human Rights Institute of South Africa, Commission of Inquiry regarding the Prevention of Public Violence and Intimidation (Goldstone Commission), http://www.hurisa.org.za/gold.htm (accessed May 26, 2011).

57. Ibid. 